\title{
Status of Creep-Fatigue Testing of Welded Alloy 617 Specimens in Support of the NGNP
}

\author{
Terry C. Totemeier
}

September 2005

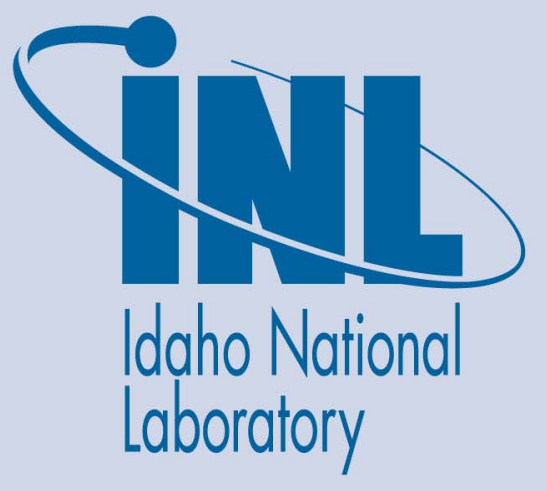

The INL is a U.S. Department of Energy National Laboratory operated by Battelle Energy Alliance 
INL/EXT-05-00781

\title{
Status of Creep-Fatigue Testing of Welded Alloy 617 Specimens in Support of the NGNP
}

\author{
Terry C. Totemeier
}

September 2005

Idaho National Laboratory

Idaho Falls, Idaho 83415

Prepared for the

U.S. Department of Energy

Office of Nuclear Energy

Under DOE Idaho Operations Office

Contract DE-AC07-05ID14517 


\section{Status of Creep-Fatigue Testing of Welded Alloy 617 Specimens in Support of the NGNP}

September 2005

Approved by 


\section{CONTENTS}

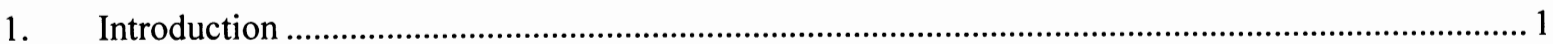

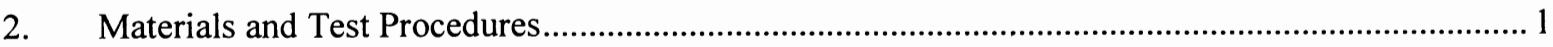

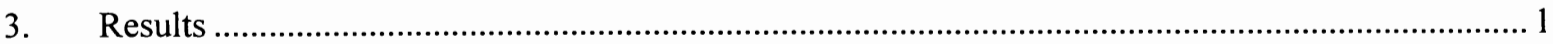

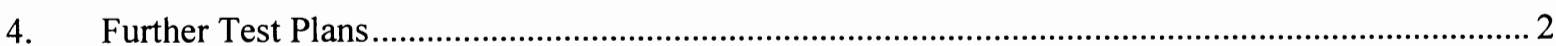

\section{FIGURES}

Figure 1. Schematic of creep-fatigue test specimen and location within welded plate.............................. 2

\section{TABLES}

Table 1. Test conditions and results for creep-fatigue of alloy 617 fusion welds at $1000^{\circ} \mathrm{C}$ in air. All tests performed with triangular waveform, strain rate $1 \times 10^{-3} \mathrm{sec}^{-1}$, fully reversed loading, tensile strain hold. 


\title{
Status of Creep-Fatigue Testing of Welded Alloy 617 Specimens in Support of the NGNP
}

\author{
1. Introduction
}

The Generation IV (GEN IV) Very High Temperature Gas-Cooled Reactor concept (VHTR) is a helium-cooled, graphite-moderated, thermal neutron spectrum nuclear reactor for the demonstration of thermodynamically efficient production of electricity and hydrogen without production of greenhouse gases. The demonstration-scale version of this reactor is referred to as the Next Generation Nuclear Plant (NGNP). For efficient production of hydrogen using a thermochemical cycle driven by nuclear process heat the reactor coolant outlet temperature must be as high as reasonably achievable, ideally in excess of $950^{\circ} \mathrm{C}$. Such temperatures will significantly challenge the temperature capability of existing materials of construction, particularly for metallic materials directly exposed to the coolant.

An important aspect of qualification of high-temperature metallic alloys for extended use at temperatures approaching $1000^{\circ} \mathrm{C}$ is better understanding of the interactions between creep, fatigue, and environment in such alloys and their joints. This report describes initial work on the creep-fatigue testing of standard chemistry alloy 617 fusion weldments in an air environment.

\section{Materials and Test Procedures}

An alloy 617 plate with standard chemistry was procured from Special Metals Corporation (Huntington, WV); butt-type gas-tungsten arc fusion welds (GTAW) were created in the plate using alloy 617 filler metal. Full details of the plate, welding parameters, and weld tensile properties were presented in report INL/EXT-05-00488, Microstructure and Strength Characteristics of Alloy 617 Welds.

Cylindrical creep-fatigue test specimens were machined from the welded plate so that the stress axis was applied across the weld joint (cross-weld specimen, Figure 1). Therefore a system consisting of the base metal, weld metal, and weld heat-affected zone (HAZ) was tested.

Initial creep-fatigue tests were performed on a refurbished creep-fatigue test system in air. Air tests were performed for ready comparison with data produced in air under a previous program and because a final determination of appropriate inert environment has not been made. Tests were performed in total axial strain control at $1000^{\circ} \mathrm{C}$. The specimens were inductively heated; the temperature variation along the $25 \mathrm{~mm}$ gauge section was less than $10^{\circ} \mathrm{C}$. A fully-reversed, triangular waveform with a strain rate of $1 \times 10^{-3} \mathrm{sec}^{1}$ was used. Creep was introduced into the test cycle by a tensile strain hold with durations ranging from 0 to 10 minutes.

\section{Results}

Table 1 lists tests performed, cycles to initiation (10\% load drop) and failure ( $25 \%$ load drop), along with data for base metal specimens tested as part of another program at equivalent conditions. Although these results are preliminary, the fusion welds appear to have markedly shorter lives than base metal at the lower strain range. At the higher strain range, tensile hold time has more of an effect in reducing creep-fatigue life for the fusion welds compared to base metal. Fatigue lives for the base metal are constant with increasing hold time for holds greater than one minute, while fusion weld fatigue lives continually decrease with increasing hold time. Detailed fractographic examination of the tested specimens has not yet been performed. 


\section{Further Test Plans}

Creep-fatigue testing of alloy 617 fusion weld specimens will continue in FY06. Tests will be performed in inert and impure He environments; no further testing in air is anticipated. Test results will be compared with similar data obtained for base metal. Fractographic examination of failed specimens will be performed to deduce micromechanisms resulting in failure.

Table 1. Test conditions and results for creep-fatigue of alloy 617 fusion welds at $1000^{\circ} \mathrm{C}$ in air. All tests performed with triangular waveform, strain rate $1 \times 10^{-3} \mathrm{sec}^{-1}$, fully reversed loading, tensile strain hold.

\begin{tabular}{lcccccc}
\hline Test ID & $\begin{array}{c}\text { Total Strain } \\
\text { Range (\%) }\end{array}$ & $\begin{array}{c}\text { Tensile Hold } \\
\text { Time (min) }\end{array}$ & \multicolumn{2}{c}{ Cycles to Initiation } & \multicolumn{2}{c}{ Cycles to Failure } \\
\cline { 5 - 7 } & & & $\begin{array}{c}\text { Fusion } \\
\text { Weld }\end{array}$ & $\begin{array}{c}\text { Equivalent } \\
\text { Base Metal }\end{array}$ & $\begin{array}{c}\text { Fusion } \\
\text { Weld }\end{array}$ & $\begin{array}{c}\text { Equivalent } \\
\text { Base Metal }\end{array}$ \\
\hline IN617-FUS-1000-06 & 0.3 & 0 & 2687 & 12,300 & 2958 & 13,400 \\
IN617-FUS-1000-07 & 0.3 & 1 & 1167 & 1200 & 1380 & 4100 \\
IN617-FUS-1000-03 & 1.0 & 0 & 417 & 400 & 545 & 570 \\
IN617-FUS-1000-04 & 1.0 & 1 & 200 & 330 & 228 & 510 \\
IN617-FUS-1000-02 & 1.0 & 3 & 179 & 240 & 204 & 400 \\
IN617-FUS-1000-05 & 1.0 & 10 & 97 & 240 & 119 & 400 \\
\hline
\end{tabular}

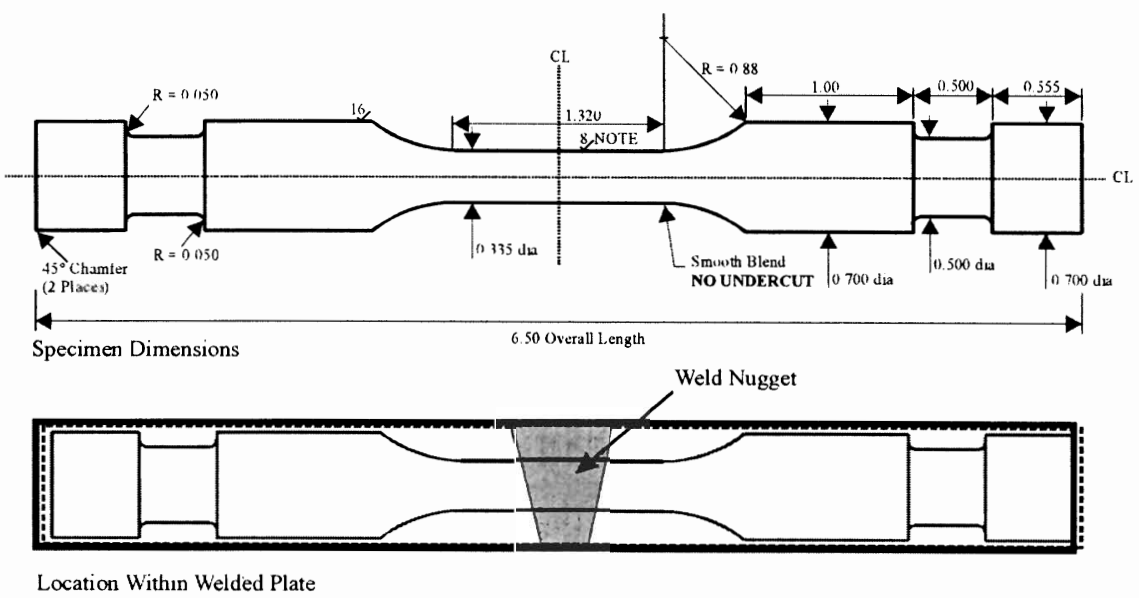

Figure 1. Schematic of creep-fatigue test specimen and location within welded plate. 